\title{
Corporate Repertoires of Control and Performances of Power in a Contested Land Deal in Senegal - ERRATUM
}

Marie Gagné

https://doi.org/10.1017/asr.2021.90, published by Cambridge University Press, 4 October 2021

In the original publication of this article (Gagné 2021), the endnotes from note 11 onward were misnumbered, such that the callouts in the text did not correspond to the correct notes. In addition, Figure 3 was incorrectly positioned at the end of the article.

The article has been updated. The publisher apologizes for this error.

\section{Reference}

Gagné, Marie. 2021. "Corporate Repertoires of Control and Performances of Power in a Contested Land Deal in Senegal.” African Studies Review 64 (3): 675-703.

African Studies Review, Volume 64, Number 4 (December 2021), pp. 992

(C) The Author(s), 2021. Published by Cambridge University Press on behalf of the African Studies Association.

doi:10.1017/asr.2021.117

992 